\title{
Early Modern Cultural Hybridity: Bartholomew Fair as a Heterotopia of Hamlet ${ }^{1}$
}

\author{
Martin Procházka \\ Charles University, Prague, Czech Republic
}

As a contribution to the discussion of Shakespeare's "appropriability" (Stanley Cavell), this paper examines some aspects of the cultural position of Hamlet on the Facobean entertainment market, as they are indicated in Ben fonson's comedy Bartholomew Fair (1614). The metatheatrical features of Bartholomew Fair may be said to measure the play's resistance against appropriating the unique and problematic aspects of Hamlet, such as the Ghost or The Mousetrap. These are deconstructed in Fonson's comedy, which anticipates the Enlightenment views of the social functioning of theatre as a "moral institution".

\section{Keywords}

Hamlet; Bartholomew Fair; hybridity; appropriation; metatheatrical; heterotopia

This paper is a contribution to the debate on Shakespeare's "appropriability" (Cavell xiii). Examining the cultural "position" (Cavell xiii) of Hamlet on the Jacobean entertainment market, as indicated in Bartholomew Fair, it also touches on the question of Shakespeare's originality.

Rather than as an inherent and fundamental quality of his works, Shakespeare's originality is approached as a retroactive and relational outcome of the appropriations of his works. As Stanley Cavell argued,

the idea of appropriability is not meant to prejudge the degree to which lines, scenes, plays may resist certain appropriations less or more than others. It is rather to make the matter of such resistance paramount in assessing cultural position, and to make measuring of resistance a matter of critical and theatrical appropriation. (xiii) 
Accordingly, the metatheatrical aspects of Bartholomew Fair may be said to measure the play's "resistance" against appropriating the problematic features of Hamlet, unique in the early modern drama, namely the Ghost and The Mousetrap. $^{2}$

Jonson's dramatic project is seen in its relations to the Jacobean public, which is expressed in the "Induction" to Bartholomew Fair. Here, Shakespeare's drama, referred to as "Tales, Tempests, and such-like drolleries" (Induction 133) is associated with the popular theatre of the past, represented by Richard Tarlton's jigs and jests. As a consequence, Jonson's "Induction" can be read as a commentary on the incompatibility of Shakespeare's idea of theatre (expressed in his speech to the actors in Hamlet 3.2) and the values characteristic of the contemporary entertainment market. In Bartholomew Fair, a parody of the ontological and representational features of the Ghost in Hamlet (its substitution by Puppet Dionysius defending theatre against the Puritan Zealof-the-Land Busy) is combined with a grotesque travesty of the intertextual framework, dramatic and theatrical functions of The Mousetrap.

Seen in this perspective, Jonson's play can be interpreted as statement of the incommensurability of Shakespeare's Renaissance humanism with the early modern commercial theatre. Jonson's criticism of early modern religious fundamentalism, market economy and consumerism in Bartholomew Fair is no longer based on Renaissance humanism, but anticipates the Enlightenment views of the social functioning of theatre as a "moral institution", expressed, for instance, in the writings of Voltaire (354; see also Kernodle 465$)$ or Schiller $(39-46) \cdot{ }^{4}$

My comparison of Hamlet and Bartholomew Fair supplants traditionally conceived originality (determined by the existence of an irreplaceable actual or hypothetical origin) with a functional notion of hybridity based on "human agency", which are sited in "social practices" (Kraidy 151). These are represented much less in Hamlet than in Bartholomew Fair. The functional understanding of hybridity emphasises the transformation potential of texts referred to by the signifier "Shakespeare", and their cultural, social and other contexts.

Unlike in genetics, where the term "transformation potential" refers to "cell transformation" producing "transgenic cells" by transferring DNA from a different organism (Rivera et al. 1; Renelli et al. 2166), in the humanities, and specifically in cultural studies, the term implies a shift of emphasis from the framework given by intertextuality (the production of meaning and value in the relations among texts) to that of intercontextuality "produced in the complex imbrication of discursive and nondiscursive practice" (Appadurai 
187). It is evident that the relationship between Hamlet and Bartholomew Fair includes a minor (though rather significant) aspect of intertextuality (a reference to the classical story of Damon and Pythias in both plays) and a substantial network of intercontextual relationships starting with those between human actors and puppets and ending with that between early modern theatre and early market capitalism.

Due to its transformation potential, "Shakespeare" as an intentional sign referring to the canon of his works (Mukařovský 87) may serve as an interface and a protocol ${ }^{5}$ enabling communication among cultures. This analogy is based on a hypothesis of a common principle of functioning of computer networks and transcultural exchange, namely on the negotiation of the ways of communication between heterogeneous or incompatible systems. Whereas interfacing in IT networks is highly formalized, transcultural communication depends on the transformation potential realized by means of human agency and intercontextuality. Similar communication as that among different cultures can also exist between diverse historical forms of a single culture. In Bartholomew Fair, these are the traditional popular theatre and Jacobean theatre within a contemporary entertainment market (McLuskie 139-56).

The transcultural communication and the negotiation involved in it are evident from the "Induction" of Jonson's comedy, alluding both to the old popular theatre and to theatre as a commodified entertainment, epitomized by the contract between the author and the audience, which is referred to as a "new" prologue to Bartholomew Fair (Induction 6o).

Research into the transformation potential of Shakespeare's theatre also involves a significant change in the understanding of time: the shift of emphasis from its universality and even "multi-temporality" ("a simultaneous assemblage, or re-presentation, of temporally disparate information", where "each present moment" contains "multiple levels of the past" Barker, Time and the Digital 96, 14) to its "polychronicity", which may be defined as the way of distinguishing time according to its diverse uses in psychic, social, cultural and many other contexts. While multi-temporality can be associated with the operation of IT protocols, which draw "together once disparate moments in time into a field of multi-temporality" (Barker, "Media Ecology" 54 ), polychronicity characterizes the behaviour of active computer users (Lee et al. 30o-16).

However, polychronicity is not restricted to computer communication. A good example of polychronicity is the complex plot structure of Bartholomew Fair which culminates in the puppet play. Here, puppets are at the same time 
"representations of human" bodies and "toy instruments", and the "boundary between props and persons" is crossed many times in both directions (Caton 68-69).

Ben Jonson's play, whose very title (appearing in a dialectal form "Bartholmew Fayre" - on the frontispieces of the early editions of 1631 and 1640) signalizes cultural hybridity, is a unique case of an early appropriation of the transformation potential of Shakespeare's drama. Confronting its poetic nature and features of popular culture with the crudeness of consumerism and the emerging market economy, it fundamentally transforms important thematic and theatrical features of Hamlet: the Ghost and The Mousetrap. The discussion of the intercontextual relationships between the two plays will have to start with the examination of their intertextuality.

The figure of the Ghost in Bartholomew Fair may at first appear as a product of intertextuality. Jonson (168n) as well as Shakespeare (318n) knew Richard Edwards's play, The excellent Comedie of two the moste faithfullest Freendes, Damon and Pithias, acted in Whitehall at Christmas 1564 and published in 1571. Their references to the story of Damon and Pythias invoke true friendship and its trials, thematized in the title of Littlewit's puppet play ("with as true a trial of friendship between Damon and Pythias" 5.3.8-9) and invoked in Hamlet's monologue addressed to Horatio before the beginning of The Mousetrap:

... Give me that man

... and I will wear him

In my heart's core, ay in my heart of heart,

As I do thee.

$$
(3 \cdot 2.64-67)^{6}
$$

Apart from Edwards's play, both playwrights most likely knew some versions of a story of Pythagoras's disciples Damon and Pythias and the Syracuse tyrant Dionysius the Younger, based on several Greek and Roman sources and made familiar by a popular collection of stories Facta et dicta memorabilia by Valerius Maximus. Shakespeare and Jonson use the story each in his own specific way, given by intercontextual, rather than intertextual relationships.

Shakespeare invokes Damon in an improvised ballad stanza:

For thou dost know, O Damon dear, This realm dismantled was 
Of Jove himself, and now reigns here

A very, very pajock.

$$
\left(3 \cdot 2 \cdot 25^{8-61)}\right.
$$

Hamlet sings these lines after his staging of The Mousetrap was interrupted by Claudius's hasty departure. His elation about the success of the play manifests itself in a hybrid show including stylistic means, such as the teasing rhyme ("pajock" instead of the unspoken "ass"), fragments of lost, or perhaps invented, ballads, and mostly nonsensical talk, as if his madness was more than pretended. His reference to Damon seems to invoke the accusation of Pythias of plotting against Dionysius. ${ }^{7}$ In his high-flown imagination, Hamlet identifies himself with Pythias, while ascribing the role of Damon to Horatio. The hybrid sequence is surprisingly concluded with the protagonist's statement resolving his doubts concerning the Ghost voiced in 2.2, and proclaiming the success of The Mousetrap as a confirmation of the truth of the Ghost's account of regicide and the way it was perpetrated: "O good Horatio, I'll take the Ghost's word for a thousand pound. Didst perceive?" (3.2.263-64)

Jonson needs Damon and Pythias in order to bring the puppet of the ghost of Dionysius to the play within the play, which is a reductive adaptation of Marlowe's poem Hero and Leander (1598), thus to fulfil its chief purpose within Bartholomew Fair, namely the defence of theatre against its Puritan detractors, represented by Zeal-of-the-Land Busy. According to the story of Damon and Pythias, as well as to Edwards's play, the ruthless tyrant was so persuaded by the power of their friendship (Pythias was ready to die for Damon) that he decided not to execute either of them and became a philosopher.

In Jonson's farcical travesty, the ghost of Dionysius comes "Not like a monarch but a master of school / In a scrivener's furred gown" $(5 \cdot 5 \cdot 324-25){ }^{8}$ The last phrase does not refer to any of the versions of the story of Damon and Pythias, but appears in historical accounts of Dionysius the Younger, who was forced to give up his throne in Syracuse and was exiled to Corinth, where "he assumed the profession of a schoolmaster, and taught children in the open streets, either that he might continually be seen in public by those who feared him, or might be more readily despised by those who did not fear him" (Justinus). ${ }^{9}$ Although Jonson might have known this story, which in his time reappeared in the book of emblems Atalanta Fugiens (1618) by German alchemist Michael Maier, who between 1611 and 1614 had stayed at the court of James I, it is rather unlikely that the playwright was alluding 
to it in Bartholomew Fair. ${ }^{10}$ Instead, Jonson refers to the most problematic representation in Shakespeare's work, the Ghost of King Hamlet.

In contrast to the ghost of Don Andrea in Thomas Kyd's Spanish Tragedy, the verisimilitude of King Hamlet's ghost is carefully constructed in theatrical as well as dramatic terms. Nonetheless, in spite of its "realistic" features, the Ghost remains a powerful illusion, and is unaffected by stage action, however violent it may be. As Marcellus says after its disappearance in the first scene:

We do it wrong, being so majestical,

To offer it a show of violence,

For it is as the air invulnerable,

And our vain blows malicious mockery.

$(1.1 .125-28)$

These lines echo the contemporary meaning of illusion - "mockery" (of the devil) - and reverse the relationship between the Ghost and stage-acting. Paradoxically, the Ghost may seem more "real" than the show on the stage. But the power of this "reality" does not stem from Aristotelian mimesis. Rather, the Ghost is so powerful because of its spectrality. According to Derrida, this spectrality differentiates it "not only from the icon or the idol but also from the image of the image, from the Platonic phantasma, as well as from the simple simulacrum of something in general to which is nevertheless so close and with which it shares, in other respects, more than other feature" (Spectres of Marx 7).

In Bartholomew Fair, Puppet Dionysius neutralizes the spectrality of King Hamlet's ghost, based on the ontological and noetic uncertainty, and transforms it into a didactic tool, helping to promulgate a new role for theatre in the nascent capitalist society. A different development can be observed in Hamlet where the friendly witness Horatio is the only, though somehow reluctant, authority to endorse Hamlet's hypothesis about the unity of the moral power and the aesthetic value of theatre, consisting in the theatrical illusion as the "cunning" and "most miraculous organ" of stage production." In contrast to Hamlet's intellectual assumptions, Jonson's puppet of the ghost (called "hobby-horse" - 5.3.136-37 - by Bartholomew Cokes, a wealthy young man who fell in love with the puppets as toys) argues about the "lawful calling" $(5 \cdot 5 \cdot 55)$ of theatre and actors, in order to defend their position within early 
modern market economy. The problem of this defence is that, in Jonson's play, theatre is finally reduced to a puppet show. Furthermore, the Ghost's argument is based on the equation of puppets with material objects (props or toys) and benefits from their substitution for the stage representation of humans.

As a result, puppets can be compared to products which satisfy human "Pride" and "Vanity" (5.5.79-80), such as fashionable clothing, feathers, wigs, ribbons, sweets, etc. This metonymical substitution, or, to use Derrida's term, the "movement of supplementarity" (Derrida, "Structure, Sign and Play" 289) emphasizes the function of theatre in the process of commodification of human desires, which includes the substitution of sexuality with the seemingly sexless commodity fetishism. This is confirmed by Puppet Dionysius's statement "we have neither male nor female amongst us" alluding to the epistle of St Paul to the Galatians: "there is neither male, nor female: for ye are all one in Christ Jesus" (Galatians 3:28).

Symptomatically, this all too easy defence of theatre, based on the assumption of the Divine unity of all creation, is undercut by irony, when Puppet Dionysius compares himself to Busy, maintaining that he speaks "by inspiration as well as he" and has "as little to do with learning as he" (5.5.108-10). This irony, subverting the banal argument which pretends to resolve metaphysical and ethical problems of the ontology of theatrical representation by reducing it to a common-sense example of a puppet play, seems to contradict the businesslike tone of the second part of the "Induction", where the Prologue-Contract censures Shakespeare for promulgating old ways of popular entertainment, such as "Tales, Tempests, and such-like drolleries" (including grotesque physical action, lowering one's imagination to popular taste "to mix his head with other men's heels" and producing "the concupiscence of jigs and dances" Induction 116-19). Here, Jonson is offering the puppets as an alternative to the popular theatre influences in Shakespeare's work: "yet if the puppets will please anybody, they shall be entreated to come in" (Induction 120).

However, the puppet play heavily frustrates all expectations of greater order or decency. While in Hamlet "puppets" are merely a tame metaphor of flirting or idle play ${ }^{12}$, in Bartholomew Fair they assert the sheer power of materialism, consumerism and obscenity. "Now mark how it works", says the puppeteer Leatherhead:

And Hero got drunk to any man's thinking,

Yet it was not three pints of sherry could flaw her, 
Till Cupid distinguished like Jonas the drawer, From under his apron where his lechery lurks, Put love in her sack.

$$
(5 \cdot 4 \cdot 269-73)
$$

"Love" is either a nondescript material addition to the "sherry" Hero is drinking, or, in connection with "sack" (which at that time meant also "vagina" Henke 229), a reference to "lechery" and a sexual act. "Jonas the drawer" is not allegorized (or disguised), but "distinguishes" himself, as "Cupid", destroying all poetic implications of this mythological figure. The volume of alcohol adulterated with some stronger drug substitutes the "dallying" of Hamlet's puppets. The main reason for all of these differences is intercontextual: the theatrical space of the Fair is a metaphor of the future society based on the market economy depending considerably on the enhancement of desire of commodities and their consumption. ${ }^{13}$

It can be concluded that Jonson's travesty opens up the tragic plot of Hamlet and its themes of theatre as a revelation of truth and a vehicle of justice. Thus, it creates a heterotopia, where some key political, moral and aesthetic problems of the day are "simultaneously represented, contested and inverted" (Foucault 24). The theatrical sign of this heterotopia, the puppet of the Ghost, points to the theoretical as well as practical problems of the time (spectrality, commodification and the contested status of the theatre $\left.{ }^{14}\right)$ and, paradoxically, inaugurates a modern utopian view of the theatre as a force for social control, integration and harmonization.

\section{Notes}

1. The research for this paper was supported by the European Regional Development Fund Project "Creativity and Adaptability as Conditions of the Success of Europe in an Interrelated World" (No. CZ.02.1.01/o.o/o.o/16_019/oooo734).

2. The problematic features of the Ghost in Hamlet chiefly include its "spectrality" precluding the determination of its ontological status and verification of its message. These aspects are discussed in detail by Derrida (Spectres of Marx 3-48) and also in my previous work (Procházka 409-22). See also Prosser (97-117) and Greenblatt (102-204). The Mousetrap staged by Hamlet as an experiment which should prove the truth of the Ghost's message and fulfil the Ghost's injunction, is also problematic in dramatic terms, especially with regard to the instructions given by Hamlet to the actors. For a summary of the long discussion on the problematic nature of The Mousetrap, see Roth (117-20). 
3. All quotations of Bartholomew Fair in this article follow Jonson's text. The act, scene and line numbers are in parentheses in the main text.

4. On Jonson's moral concept of literature see, e.g., Scott-James (120-28).

5. In computer science, "an interface refers to the connecting point between two adjacent network entities. A protocol defines rules to be complied with for exchanging information on the connecting point" (All About Wireless Telecommunication). For the general scheme of the connection of interfaces and protocols among different network layers see Perlman (2). For a detailed analysis of computer protocols in relation to control, power and Internet art see Galloway (2-27).

6. All quotations from and references to Hamlet in this article follow The Norton Shakespeare. The act, scene and line numbers are in parentheses in the main text.

7. In Edwards's play the fates of the two friends are reversed: Damon is accused of spying and sentenced to death for preparing a military attack on Syracuse. Pythias offers himself as a hostage in exchange for Damon, when he is allowed by Dionysius to return to Greece to settle his affairs before death (Edwards $\left.32,3^{6}\right)$.

8. The link of the ghost and the "scrivener's gown" may associate the Scrivener from the "Induction" who reads the disparaging comments on Shakespeare (Induction, 132-34).

9. The role of schoolmaster in this version is a mere disguise for a former tyrant, who has lost all his dignity.

10. In fact, Maier's book denies the veracity of the story: "Neither could he have come to Corinthus, there to set up a School to teach boyes and profess humane learning. From a King being made a Schoolmaster and wielding a rod instead of a Scepter, the proverb originated: 'Dionysius of Corinth"' (Maier 92).

11. "I have heard that guilty creatures sitting at a play / Have by the very cunning of the scene / Been struck so to the soul that presently / They have proclaimed their malefactions; / For murder, though it have no tongue will speak / With most miraculous organ" (2.2.566-71). "Would not this [i.e., The Mousetrap] ... get me a fellowship in a cry of players, sir?" $(3 \cdot 2.253,255)$. The latter remark is ironized in Horatio's reply: "Half a share" $(3 \cdot 2 \cdot 256)$.

12. In Hamlet $\left(3 \cdot 2 \cdot 225^{-2} 6\right)$ the protagonist says to Ophelia: "I could interpret between you and your love if I could see the puppets dallying."

13. " $[\mathrm{P}]$ ickled herrings were ... regarded as an exotic promoter of alcoholic consumption in London" (Katritzky 163). The consumption of alcohol was also enhanced by various other "exotic" commodities, including "Westphabian [i.e., Westphalian] bacon" (5.5.294) brought by Damon and Pythias to win the love of Hero.

14. See Derrida (Spectres of Marx 3-48). For the development of Derrida's approach see Procházka (409-22).

\section{Works Cited}

Appadurai, Arjun. Modernity at Large: Cultural Dimensions of Globalization. Minneapolis, MN and London: University of Minnesota Press, 1996. Print. 
Barker, Timothy Scott. Time and the Digital: Connecting Technology, Aesthetics, and a Process Philosophy of Time. Hanover, NH: Dartmouth College Press/ University Press of New England, 2012. Print.

--. "Media Ecology in Michel Serres's Philosophy of Communication." Techné: Research in Philosophy and Technology, vol. 19, no. 1. 2015: 50-68. Print. DOI: 10.5840/techne201532327.

Caton, Kristina E. "Shared Borders: The Puppet in Ben Jonson's Bartholomew Fair." Early Theatre, vol. 16, no. 1. 2013: 51-73. Print. DOI: http://dx.doi. org/10.12745/et.16.1.4.

Cavell, Stanley. "Foreword." Philosophical Shakespeares. Ed. John J. Joughin. London and New York: Routledge, 2000. xii-xvi. Print.

Derrida, Jacques. Spectres of Marx. Trans. Peggy Kamuf. London and New York, NY: Routledge, 1993. Print.

--. "Structure, Sign and Play in the Discourse of the Human Sciences." Writing and Difference. Trans. Alan Bass. Chicago, IL and London: University of Chicago Press, 1978. 278-93. Print.

Edwards, Richard. The excellent Comedie of two the moste faithfullest Freendes, Damon and Pithias. The Dramatic Writings of Richard Edwards, Thomas Norton and Thomas Sackville. Ed. John S. Farmer. London: Early English Drama Society, 1906. Print.

Foucault, Michel. "Of Other Spaces: Utopias and Heterotopias." Trans. Jay Miskowiec. Diacritics, vol. 16, no. 1. 1986: 22-27. Print.

Galloway, Alexander R. Protocol: How Control Exists after Decentralization. Cambridge, MA: The MIT Press, 2004. Print.

Greenblatt, Stephen. Hamlet in Purgatory. Princeton, NJ: Princeton University Press, 2001. Print.

Jonson, Ben. Bartholomew Fair. Revels Student Edition. Ed. Suzanne Gossett. Manchester: Manchester University Press, 2000. Print.

Justinus, Marcus Junianus. Epitome of the Philipic History of Pompeius Trogus. Ed. and Trans. John Selby Watson. London: Henry G. Bohn, 1853, XXI.5. Accessed 24 July 2017. Web. http://www.forumromanum.org/literature/ justin/english/trans21.html\#n4.

Katritzky, M.A. “'A plague o' these pickle herring': From London Drinkers to European Stage Clown.” Renaissance Shakespeare: Shakespeare Renaissances. Eds. Martin Procházka, Michael Dobson, Andreas Höfele and Hanna Scolnicov. Lanham, MD: Rowman and Littlefield, 2014. 159-69. Print.

Kernodle, George Riley. The Theatre in History. Fayetteville, AR, and London: The University of Arkansas Press, 1989. Print. 
Galatians 3:28. King James Bible. Accessed 24 June 2017. Web. https:// biblehub.com/galatians/3-28.htm.

Henke, James T. Courtesans and Cuckolds: A Glossary to Renaissance Dramatic Bawdy. New York, NY: Garland Publishing, 1979. Print.

Kraidy, Marwan M. Hybridity, or the Cultural Logic of Globalization. Delhi: Pearson Education, 2007. Print.

Lee, Waipeng, Trevor M. K. Tan and Shahiraa Shahul Hameed. "Polychronicity, the Internet, and the Mass Media: A Singapore Study." Journal of ComputerMediated Communication, vol. 11, no. 1. 2006: 300-16. Print.

Maier, Michael. Atalanta Fugiens. Oppenheim: Johann Theodor de Bry, 1618. Accessed 24 July 2017. Web. http://93beast.fea.st/files/section1/maier/ Maier\%20-\%2oAtalanta\%2oFugiens.pdf.

McLuskie, Kate. "Making and Buying: Ben Jonson and the Commercial Theatre Audience." Refashioning Ben Fonson: Gender Politics and the Fonsonian Canon. Eds. Julie Sanders, Kate Chedgzoy and Susan Wiseman. Basingstoke and New York, NY: Macmillan/St. Martin's, 1998. 134-56. Print.

Mohammed (Blogger). "Interfaces and Protocols." All About Wireless Telecommunication. 19 February 2011. Accessed 24 June 2018. Web. http:// allaboutwirelesstelecommunication.blogspot.com/2011/o2/interfaces-andprotocols.html.

Mukařovský, Jan. "Umění jako sémiologický fakt." ("Art as a Semiological Fact."). Studie z estetiky (Studies in Aesthetics). Prague: Odeon, 1966. 85-88. Print.

Perlman, Radia. Interconnections: Bridges, Routers, Switches, and Internetworking Protocols. Second edition. Boston, MA: Addison Wesley Longman, 2000. Print.

Procházka, Martin. "From 'Affirmative Culture' to the 'Condition of Justice': A Reading of a Czech Post-Communist Hamlet." Arbeit am Gedächtnis. Eds. Michael Frank and Gabriele Rippl. München: Wilhelm Fink Verlag, 2006. 409-22. Print.

Prosser, Eleanor. Hamlet and Revenge. Stanford, CA: Stanford University Press, 1967. Print

Renelli, Marika, Valério Matias, Reggie Y. Lo and Terry J. Beveridge. "DNAcontaining Membrane Vesicles of Pseudomonas aeruginosa PAO1 and Their Genetic Transformation Potential." Microbiology, 150. 2004: 2161-69. Print.

Rivera, Ana Leonor, Lim M. Gomez, F. Fernández, A.M. Loske. "Genetic Transformation of Cells Using Physical Methods." Fournal of Genetic 
Syndromes \& Gene Therapy, vol. 5, no. 4. 2014: 1-6. n. Print. DOI: 10.4172/21577412.1000237.

Robertson, J. G. Lessing's Dramatic Theory: Being an Introduction and Commentary on His Hamburgische Dramaturgie. Cambridge: Cambridge University Press, 1939. Print.

Roth, Steve. Hamlet: The Undiscovered Country. Seattle, WA: Open House, 2009.

Schiller, Friedrich. "Die Schaubühne als eine moralische Anstalt betrachtet" (1784/1802). Schillers Sämtliche Werke, vol. 4. Stuttgart: J. G. Cotta'sche Buchhandlung, 1879. 39-46. Print.

Scott-James, R. A. The Making of Literature. New Delhi: Allied Publishers, 1988. Print.

Shakespeare, William. Hamlet. Arden Shakespeare. 3rd series. Eds. Ann Thompson and Neil Taylor. London: Cengage Learning, 2006. Print.

The Norton Shakespeare. Gen. Ed. Stephen Greenblatt. New York, NY: W.W. Norton and Co., 1997. Print.

Voltaire. "A un premier commis" (1733). Euvres complètes de Voltaire, vol. 33, Correspondance I. Paris: Garnier, 1880. 354. Print.

MARTIN PROCHÁZKA is Professor of English, American and Comparative Literature at Charles University, Prague. He is the author of Romanticism and Personality (1996, in Czech), Transversals (2008) and Ruins in the New World (2012) and a co-author of Romanticism and Romanticisms (2005, in Czech). He is a Trustee of the International Shakespeare Association (ISA), an Advisory Board member of the International Association of Byron Societies (IABS), the founding editor of the international academic journal Litteraria Pragensia and a visiting professor at the Universities of Kent and Porto.

martin.prochazka@ff.cuni.cz 